suggest that ibuprofen has minor effects on the cardiovascular system, but our experience points to the contrary.

Care should be exercised in prescribing ibuprofen to people who are liable to take overdoses.

We thank Mr L Higginbotham, department of biochemistry, Royal Manchester Children's Hospital, and the poisons unit, New Cross Hospital, for their analyses, and Boots Company Limited for their help.

${ }^{1}$ Adams SS, Bough RG, Cliffe EE, et al. Absorption and distribution and toxicity of ibuprofen. Toxicol Appl Pharmacol 1969;15:310-30.

(Accepted 22 September 1980)

Department of Medicine, Hope Hospital, Salford M6 8HD

DIANA P HUNT, MB, CHB, senior house officer

RICHARD J LEIGH, MB, MRCP, tutor in medicine

\section{Plasma exchange to control sweats and pruritus in malignant disease}

Pruritus and sweating attacks in malignant diseases such as the lymphomas are well recognised and disappear with successful treatment of the malignancy. Cimetidine, a potent histamine $\mathrm{H}_{2}$-receptor antagonist, controls these symptoms in Hodgkin's disease, ${ }^{1}$ but their pathogenesis is not explained. If pruritus and sweating were caused by metabolically active substances released into the plasma by the tumour such substances might be removed by plasma exchange. ${ }^{2}$ We have tested this idea and report our preliminary findings.

\section{Case reports}

Case 1-A 54-year-old woman had non-Hodgkin's lymphoma (diffuse poorly differentiated lymphocytic) diagnosed in October 1977. She had lef supraclavicular and epigastric masses and complained of general ill health and severe generalised itch. She initially responded well to cyclical administration of mustine hydrochloride, vinblastine, procarbazine, and prednisolone, with disappearance of the itch; but this and subsequent responses to chlorambucil, vinblastine, procarbazine, and prednisolone and then doxorubicin, bleomycin, vincristine, and dacarbazine were not maintained. In autumn 1979 she received palliative radiotherapy to an abdominal mass. General ill health, wasting, and intractable itch continued, the itch being unrelieved by cimetidine $800 \mathrm{mg}$ daily. A therapeutic trial of plasma exchange was conducted with a Hemonetics model 30 cell processor, with human pooled fresh-frozen plasma as replacement solution. On the first occasion 4.91 plasma was removed, and eight days later 4.3 1 . Itching disappeared after the first exchange and remained virtually absent for several weeks. No other treatment was given. She died two months after the plasma exchange.

Case 2-A 53-year-old man had a left nephrectomy for renal carcinoma in April 1979. Radiography showed numerous small discrete lung metastases and he was treated for four months with iphosphamide at three-week intervals, with no evidence of progression. Lung metastases then enlarged and tamoxifen was substituted but discontinued after only two months because of progressive disease. There was a painless mass in the nephrectomy scar $5 \times 4.5 \mathrm{~cm}$. His only notable symptom was severe night sweats. Plasma exchange performed as in case 1 (3.4 1 plasma removed initially) resulted in an immediate and sustained reduction in the number and severity of night sweats, with only light sweating occurring not more than twice weekly. Four further plasma exchanges $(3 \cdot 3,4 \cdot 6,4 \cdot 0$, and 3.61$)$ were conducted over the next nine weeks. The mass in the nephrectomy scar regressed to $4 \times 3 \mathrm{~cm}$ but the lung metastases continued to enlarge. No other treatment was given. Medroxyprogesterone acetate $100 \mathrm{mg}$ thrice daily was prescribed two weeks after the fifth plasma exchange, though the light sweating at night had not increased beyond twice a week.

\section{Comment}

From these observations plasma exchange may control severe itching or sweating in advanced malignancy when drugs have failed to do so. This apparently confirms the suggestion that itching and sweating are caused by circulating factors produced by the tumour or as a host response, though it does not exclude the possible effect of an active blocking factor added by the fresh-frozen plasma. The results justify further investigation of plasma exchange to elucidate the mechanisms producing the symptoms. It may be possible to isolate circulating factors in extracorporeal blood with in-series selective affinity columns ${ }^{3}$ and use dialysis of exchanged plasma to establish their nature and physical characteristics.

J $M$ Trotter was in receipt of a grant from Roussel Laboratories Limited. We thank Dr T Habeshaw for referring one of the patients.

Aymard JP, Lederlin P, Witz F. Cimetidine for pruritus in Hodgkin's disease. $\mathrm{Br}$ Med $\mathcal{f} 1980 ; 280: 151-2$.

2 Trotter JM, Shaw D, Carlyle E, Shephard J, Calman KC. Nutritional aspects of plasma exchange in cancer patients. In: Serrou B, ed. Immune complexes and plasma exchange in cancer patients. Amsterdam: Elsevier North Holland (in press).

3 Terman DS, Yamamoto T, Mattioli M. Extensive necrosis of spontaneous canine mammary adenocarcinoma after extracorporeal perfusion over Staphylococcus aureus cowans I. $\mathcal{F}$ Immunol 1980, 124:795-805.

(Accepted 22 September 1980)

University Department of Pharmacology and Therapeutics, Ninewells Hospital and Medical School, Dundee DD1 9SY

D SHAW, MD, MRCP, lecturer in therapeutics

University Department of Clinical Oncology, Gartnaval General Hospital, Glasgow G12 9LY

J M TROTTER, MB, FRACP, research fellow

K C CALMAN, MD, PHD, professor of clinical oncology, Cancer Research Campaign

\section{Oxprenolol and retroperitoneal fibrosis}

Retroperitoneal fibrosis is a fairly rare cause of impaired renal function. Methysergide taken for migrain ${ }^{1}$ and also abuse of analgesic drugs have been implicated in some earlier cases. Recently it has been reported in patients who had taken the beta-blocker atenolol. ${ }^{2}{ }^{3} \mathrm{We}$ report retroperitoneal fibrosis occurring in a patient who had been taking oxprenolol for five years.

\section{Case report}

In June 1979 a 53-year-old male charge nurse was referred by his general practitioner because of a persistently raised blood urea concentration of 23.0 $\mathrm{mmol} / 1(140 \mathrm{mg} / 100 \mathrm{ml})$, mild anaemia (haemoglobin $10 \cdot 1 \mathrm{~g} / \mathrm{dl}$ ), and raised erythrocyte sedimentation rate (ESR) at $62 \mathrm{~mm}$ in $1 \mathrm{~h}$, Westergren. He had suffered from angina pectoris for four years and mild ankle swelling in the preceding 6 months. In 1974 he had been started on oxprenolol $80 \mathrm{mg}$ twice daily for hypertension. In 1978 oxprenolol had been changed to Slow Trasicor $160 \mathrm{mg}$ once daily, and for about the past six months he had also been taking Adalat $10 \mathrm{mg}$ three times daily and Hygroton $\mathrm{K} 50 \mathrm{mg}$ once daily.

When referred to us his blood urea was $20.0 \mathrm{mmol} / 1(120 \mathrm{mg} / 100 \mathrm{ml})$, haemoglobin $10.7 \mathrm{~g} / \mathrm{dl}$, serum creatinine $340 \mu \mathrm{mol} / 1(3.4 \mathrm{mg} / 100 \mathrm{ml})$, and his creatinine clearance was $31 \mathrm{ml} / \mathrm{min}$. He was admitted for investigation. Clinical examination was unremarkable. His blood pressure was well controlled at $120 / 70 \mathrm{~mm} \mathrm{Hg}$ and his pulse regular at $72 / \mathrm{min}$. His ESR was $114 \mathrm{~mm}$ in $1 \mathrm{~h}$. A high-dose intravenous pyelogram showed poor excretion of contrast medium by both kidneys, a large left-sided hydronephrosis, and the ureters displaced medially. Retroperitoneal fibrosis was diagnosed and confirmed at operation, when dense fibrous tissue was found extending retroperitoneally down into the pelvis and around both ureters. Multiple specimens of tissue were taken for biopsy and bilateral ureterolysis performed. Biopsy specimens showed dense collagenous, relatively acellular fibrous tissue with no evidence of vasculitis and no malignant cells. The appearances were typical of retroperitoneal fibrosis. Postoperative recovery was uneventful and he was discharged well without a hypotensive drug. At follow-up two months later his blood urea concentration had fallen to $11.0 \mathrm{mmol} / 1$ (66 $\mathrm{mg} / 100 \mathrm{ml})$ and serum creatinine concentration to $215 \mu \mathrm{mol} / 1(2 \cdot 15 \mathrm{mg} / 100$ $\mathrm{ml}$ ), and his creatinine clearance had increased to $42 \mathrm{ml} / \mathrm{min}$. Clinically the only abnormal finding was a blood pressure of $170 / 100 \mathrm{~mm} \mathrm{Hg}$. He was started on a thiazide diuretic. The only other drug he has taken since is glyceryl trinitrate for angina pectoris.

\section{Comment}

The histological appearance of retroperitoneal fibrosis occurring in association with ingestion of methysergide does not differ from that not known to be associated with drug ingestion. The appearance of 
the lesion, therefore, cannot be used as evidence of any cause and effect relationship to drug treatment. Fibroblastic reactions in other areas have been associated with the beta-blocker practolol, ${ }^{4}$ and psoriatic skin lesions and dry eyes have occurred after treatment with oxprenolol. ${ }^{5}$ But, so far as we know, retroperitoneal fibrosis has not been reported in association with oxprenolol. Retroperitoneal fibrosis is a serious condition which is easily overlooked. It has been reported in association with another beta-blocker, and it should be considered in any patient taking a beta-blocker who develops chronic impairment of renal function.

${ }^{1}$ Graham JR. Methysergide for prevention of headache: experience in five hundred patients over three years. $N$ Engl f Med 1964;270:67-72.

2 Doherty CC, McGeown MG, Donaldson RA. Retroperitoneal fibrosis after treatment with atenolol. $\mathrm{Br}$ Med $\mathcal{F} 1978$;ii: 1786.

3 Johnston JN, McFarland JB. Retroperitoneal fibrosis associated with atenolol. $\mathrm{Br}$ Med $\mathcal{F}$ 1980;280:864.

4 Erwteman TM, Braat MCP, Van Aken GM. Interstitial pulmonary fibrosis: A new side effect of practolol. $\mathrm{Br}$ Med $\mathcal{f} 1977$;ii :297-8.

${ }^{5}$ Hudson WA, Finnis WA. Oxprenolol and psoriasis-like eruption. Lancet $1975 ; \mathrm{i}: 932$.

(Accepted 2 October 1980)

Department of Nephrology, Belfast City Hospital, Belfast BT9 7AB

DAVID R MCCLUSKEY, MB, MRCP, registrar in nephrology

RICHARD A DONALDSON, MC, FRCP, consultant urologist

MARY G MCGEOWN, MD, FRCP, consultant nephrologist

\section{Homosexual behaviour after vasectomy}

Vasectomy has become increasingly popular as a safe, simple, and reliable method of male sterilisation. In the absence of pre-existing marital and sexual problems and with the informed consent of both the husband and wife vasectomy generally has no adverse effects on the marital relationship. ${ }^{1}$ We report the case of a patient whose sexual orientation changed after vasectomy.

\section{Case report}

A 32-year-old married man was seen at a clinic for sexual problems, at the request of his wife, nine months after he had had a vasectomy. Within six weeks of the operation he had experienced, for the first time in his life, homosexual feelings which had led him to embark on a sexual relationship with a man. In stable employment for the previous 12 years, he worked responsibly and was highly esteemed by his employers. He was a reserved, self-sufficient person with no history of psychiatric disturbance. The middle of three sons, he described a happy, secure childhood during which he could not recall any effeminate behaviour. He had developed an interest in girls during early adolescence and denied feeling anxious in female company. His first heterosexual relationship at the age of 15 had amounted only to petting, and during the ensuing 10 years he had enjoyed relationships with six other women. He had had no previous sexual deviation and throughout adolescence he had masturbated regularly with heterosexual fantasies. At 25 he had married a woman of similar age after a five-month courtship. Sexual activity occurred 8 to 10 times a week during the early years of marriage and was initiated by both partners. His sexual drive and erectile potency contributed to an active and fulfilling sexual life. After the birth of their second child the couple decided, after careful deliberation and by mutual consent, that a vasectomy would provide the most acceptable method of birth control.

Within six weeks of the operation his homosexual thoughts and fantasies began to emerge. His sexual interest in his wife declined to negligible levels. His masturbatory fantasies became exclusively homosexual and preoccupying and were not unpleasant or disagreeable. Three months after the operation he started a homosexual relationship. Homosexual activity occurred daily, the patient adopting both the active and passive roles in sexual acts with his partner. At no stage did he spontaneously request treatment to suppress his sexual behaviour. One year after vasectomy he continues to live with his wife but remains preoccupied with his homosexual partner.

\section{Comment}

There have been several reports of psychiatric and sexual problems after and apparently related to vasectomy. ${ }^{2} 3$ In one study three couples with no pre-existing sexual problems suffered serious physical sexual deterioration with complete impotence, vaginismus, and persistent premature ejaculation. ${ }^{3}$ Such reactions are rare and the likelihood of their occurrence can be diminished by effective preoperative counselling. ${ }^{4} \mathrm{~A}$ change in sexual orientation after vasectomy is exceedingly rare, and we are not aware of previous reports.

Although a causal connection between the vasectomy and the ensuing change in sexual orientation in our patient cannot be proved, the operation was probably the precipitating event in a predisposed person. The concept of latent or well-compensated homosexuality has been invoked to explain a type of person in whom homosexual feelings may be unconscious and whose homosexuality may come to light during times of stress. ${ }^{5}$ Had our patient not undergone vasectomy perhaps some other event would have served to make his "latent" homosexuality manifest. In any event, such an outcome could not have been predicted by a preoperative assessment. Indeed, it would have revealed a vigorously heterosexual and potent man with no previous experience of homosexual feelings or activities. He found his change in sexual orientation a rewarding experience and expressed no desire to alter it.

Requests for reprints should be addressed to Dr C M Bass.

${ }^{1}$ Vaughn RL. Behavioural response to vasectomy. Arch Gen Psychiatry $1979 ; 36: 815-21$.

${ }^{2}$ Ziegler FJ. Vasectomy and adverse psychological reactions. Ann Intern Med 1970;73:853.

3 Wolfers H. Psychological aspects of vasectomy. Br Med f 1970;iv:297-300.

4 Lear H. Psychosocial characteristics of patients requesting vasectomy. $\mathcal{J}$ Urol 1972;108:767-9.

${ }^{5}$ Scott PD. Homosexuality, with special reference to classification. Proc Roy Soc Med 1957;50:655-60.

(Accepted 2 October 1980)

Department of Psychological Medicine, King's College Hospital Medical School, London SE5 9RS

CHRISTOPHER BASS, MRCPSYCH, lecturer

St Thomas's Hospital, London SE1

DAVID REES, FRCS, locum consultant urologist

\section{Spontaneous disappearance of psoriasis as presenting feature of oat-cell carcinoma of lung}

Oat-cell carcinoma of the lung and ectopic production of adrenocorticotrophic hormone is a well-recognised phenomenon. ${ }^{1}$ We describe a patient whose initial "complaint" was spontaneous cure of lifelong psoriasis.

\section{Case report}

A 68-year-old woman was admitted to this hospital after referral from her general practitioner. Seven weeks before, and over 10 days, her lifelong and extensive psoriasis had completely disappeared. Since childhood she had had lesions on hands, elbows, knees, legs, trunk, and in her scalp, and for about the past 15 years she had given up trying to cure them with "messy creams." One week before admission she had had an episode of haemoptysis, and radiography had shown collapse of the right lower lobe. She had smoked 20 cigarettes a day all her adult life. On examination she looked Cushingoid, and there was no evidence of any psoriatic lesion. She had a collapsed right lower lobe and enlargement of the liver.

Bronchoscopy showed a friable tumour protruding up the right main bronchus, which on biopsy proved to be an oat-cell carcinoma of the lung. She had glycosuria and a fasting blood glucose concentration of $10 \mathrm{mmol} / \mathrm{l}$ $(180 \mathrm{mg} / 100 \mathrm{ml})$. Full blood count was normal, erythrocyte sedimentation rate $16 \mathrm{~mm}$ in first hour, and measurement of urea and electrolyte concentrations disclosed hypokalaemic alkalosis (sodium $141 \mathrm{mmol}(\mathrm{mEq}) / \mathrm{l}$, potassium $2.9 \mathrm{mmol}(\mathrm{mEq}) / 1$, chloride $100 \mathrm{mmol}(\mathrm{mEq}) / 1$, carbon dioxide 32 $\mathrm{mmol} / 1(14 \mathrm{ml} / 100 \mathrm{ml})$, urea $5.9 \mathrm{mmol} / 1(35.5 \mathrm{mg} / 100 \mathrm{ml})$, creatinine 87 $\mu \mathrm{mol} / 1(1.0 \mathrm{mg} / 100 \mathrm{ml}))$. Twenty-four hour urinary free cortisol concentrations were raised on three occasions (mean $11.0 \mu \mathrm{mol} / 24 \mathrm{~h}(4.0 \mathrm{mg} / 24 \mathrm{~h}$ ); our reference range $0 \cdot 2-1 \cdot 0 \mu \mathrm{mol} / 24 \mathrm{~h}(0 \cdot 1-0 \cdot 4 \mathrm{mg} / 24 \mathrm{~h})$ ). Plasma cortisol concentrations at 8 am and 12 midnight (our reference ranges 190-720 and $<220 \mathrm{nmol} / 1(6.9-26.1$ and $<8.0 \mu \mathrm{g} / 100 \mathrm{ml})$ respectively) were 1680 and 1700 $\mathrm{nmol} / 1 \mathrm{~s}(61.0$ and $61.6 \mu \mathrm{g} / 100 \mathrm{ml}$ ) and diurnal rhythm was lost. Serum adrenocorticotrophic hormone concentration was $334 \mathrm{ng} / 1$ (our reference range $10-80 \mathrm{ng} / \mathrm{l}$ ). Liver alkaline phosphatase activity was $530 \mathrm{IU} / 1$ (normal $90 \mathrm{IU} / \mathrm{l}$ ) and liver scan confirmed multiple filling defects consistent with 